\title{
AZ ÉNEK-ZENE OKTATÁS MEGÚJULÁSÁNAK LEHETŐSÉGEI
}

\section{POSSIBILITIES FOR RENEWAL OF MUSIC EDUCATION}

\author{
Janurik Márta \\ PhD, Szegedi Tudományegyetem Zenemúvészeti Kar, MTA-SZTE Ének-Zene Szakmódszertani Kutatócsoport \\ janurikm@music.u-szeged.hu
}

\begin{abstract}
ÖSSZEFOGLALÁS
Az utóbbi évtizedek során folytatott transzferhatás-vizsgálatok és neurológiai kutatások számos bizonyítékát nyújtják a zeneoktatás sokoldalú személyiségfejlesztő hatásainak. Ezek a kutatási eredmények azonban a közvélemény számára nem kellően ismertek. Hazai motivációkutatások az ének-zene tantárgy súlyos presztízsvesztését igazolják. Az iskolai ének-zene oktatás számos problémával küzd, az alkalmazott módszerek és eszközök, a jelenlegi lehetőségek kevéssé járulnak hozzá ahhoz, hogy a zenei nevelés pozitív hatásai érvényre juthassanak. Az oktatás módszertani eszköztárából hiányoznak a fiatalok számára aktív, örömteli és kihívást jelentő tevékenységek. A 21. századi digitális technológiai eszközök által kínált oktatási lehetőségek szintén kiaknázatlanok. Hiányoznak a használatukhoz kapcsolódó feladatbankok, módszerek, a pedagógusok továbbképzése sem megoldott. Mindezek következtében az általános és középiskolás tanulók ének-zene órák iránti motiválatlansága, érdektelensége jellemző, nem kedvelik az éneklést és az órákon folytatott zenei tevékenységeket. A fiatalok többsége számára pedig a klasszikus zene megközelíthetetlen, és zenei képességeikkel összefüggő énképük is negatív. Tanulmányunkban olyan, elsősorban hazai motivációkutatások, attitűdvizsgálatok, képességvizsgálatok eredményeit ismertetjük, amelyek a helyzetfeltáráshoz járulnak hozzá, valamint az ének-zene órák módszertanának megújulási lehetőségeit is bemutatjuk.
\end{abstract}

\section{ABSTRACT}

The transfer effect investigations and neurological research of the last decades provided many proofs for the effect of music education on the development of personality. However, these results have not been popularised and integrated in education so far. Hungarian motivation research has revealed a heavy loss of prestige of music as a school discipline lately. Music education suffers from many problems: methods and tools do not promote the positive effects of music education. Joyful and challenging activities are lacking from the methodology of education.

Tools of the $21^{\text {st }}$ century digital technology are not utilized either. Relevant exercise databases and tools are lacking; there are no suitable educational efforts in this direction either. Consequently, elementary and secondary school pupils are unmotivated and uninterested in singing lessons at school. In addition, classical music is inaccessible for the majority of young people, and their self-image related to their musical abilities is negative as well. In this paper, we present results primarily of Hungarian studies on attitudes and skill which contribute to the exploration of these problems and besides, we discuss the possibilities of renewal of music education at school. 
Kulcsszavak: ének-zene oktatás, zenei nevelés, módszertani kutatás, attitűd, motiváció, IKT

Keywords: music education, methodological research, attitude, motivation, ICT

Az iskolai oktatás módszertani megújulásában fontos szerepe lehet azoknak a 2016-ban kezdődött, négyéves tantárgy-pedagógiai kutatásoknak, amelyek a Magyar Tudományos Akadémia támogatásával valósulnak meg. Az ének-zene oktatás ezzel komoly lehetőséget kapott, hiszen ezen a területen két kutatócsoport is kutatásokat kezdhet.

A hazai ének-zene oktatás hagyományosan Kodály Zoltán zenei nevelési koncepcióján alapul. Fontos azonban kiemelnünk, hogy Kodály nem törekedett részletes módszertan kidolgozására. A mindenkori zenepedagógia feladata és felelőssége, hogy megtalálja azokat a módszereket és eszközöket, amelyek segítségével a folyamatosan változó társadalmi, gazdasági környezetben céljai: a zenével való nevelés, a sokoldalú készség- és képességfejlesztés élményszerü zenei tevékenységek során valósulhatnak meg. Az ének-zene oktatás módszertani megújulásának szükségességét a zenepedagógusok, zenemüvészek gyakorlati tapasztalatai mellett az utóbbi években hazai motivációkutatások és attitűdvizsgálatok is alátámasztják. A több évtizede folytatott transzferhatás-vizsgálatok alapján pedig a zenetanulás kognitív fejlődésre gyakorolt hatása is kimutatható. Az alább ismertetendő kutatások eredményei a továbblépéshez, a megújuláshoz is szempontokat nyújtanak.

\section{AZ ÉNEK-ZENE OKTATÁS HELYZETE ÉS LEHETŐSÉGEI AZ EMPIRIKUS KUTATÁSOK TÜKRÉBEN}

Az ének-zene oktatás legfőbb neuralgikus pontját az órákon tapasztalható általános motiválatlanság jelenti. Flow kérdőív alkalmazásával folytatott vizsgálati eredményeink szerint az irodalom- és a matematikaórákkal való összehasonlításkor a legkevesebb pozitív élmény, a legtöbb szorongás, valamint a legtöbb unalom és apátia az énekórákhoz kapcsolódik (Janurik, 2009). Szintén a belső motiváció alacsony mértékét erősíti meg Józsa Krisztián, Kis Noémi és Huang Su-Ying (2017). Eredményeik szerint az örömteli tanulás legfontosabb belső mozgatóerejét jelentő elsajátítási motiváció a magyar tanulók körében, a taiwani tanulókkal ellentétben, valamennyi iskolai tantárgy esetében csökkent. A legnagyobb visszaesés azonban az ének-zene tanulása kapcsán mutatható ki. Az énekórai tevékenységek egyáltalán nem kedveltek vagy közömbösek a tanulók számára. Az ének-zene oktatás presztízsére jellemző, hogy a diákok az énekórát tartják a legfeleslegesebb és a leghaszontalanabb tantárgynak, a szülők szintén az utolsó helyre, a tanárok pedig az utolsó előtti helyre sorolják. Ilyen körülmények között 
az ének-zene oktatás legfontosabb céljai ellehetetlenülnek, a fiatalok nem jutnak el a zenei megismerés nyújtotta örömhöz. A klasszikus zene semmilyen mondanivalót nem hordoz számukra: 80 százalékuk iskolán kívül soha nem hallgatja, vagy csak nagyon ritkán, minden harmadik tanuló pedig teljes mértékben elutasítja (Janurik, 2009).

Az énekórákon folytatott zenei tevékenységekhez és a komolyzenéhez füződő negatív attitüd és motiválatlanság kialakulásának egyik oka lehet, hogy a fiatalok nagy része téves elképzelésekkel rendelkezik saját zenei képességeiről és zenei fejlődési lehetöségeiről. A készségtárgyak közül a zenei fejlődést látják leginkább az adottságok által meghatározottnak. Az összetettebb zenei képességek alapját a zenei percepció fejlettsége jelenti. A zenei percepció két elkülönülö területe a hallás utáni megkülönböztetés, illetve a hallás utáni reprodukció (éneklés és ritmustapsolás), amelyek fejlettsége között nincs erős összefüggés; óvodáskorban nincs kapcsolat, de még hetedik osztályban is csak közepesnél gyengébb a korreláció. A hallás utáni megkülönböztetés készségeiről - és ezek fejlettségéről - a hetedik osztályos tanulóknak azonban nincsen tudomásuk. Zenei képességeik fejlettségéről, ezzel együtt az előrelépés lehetőségeiről kizárólag az éneklés fejlettsége alapján döntenek. A zenei képességekkel kapcsolatos negatív énkép kialakulásához hozzájárul, hogy az éneklésben nem eléggé gyakorlottak, nagy részük pedig a valóságosnál negatívabban vélekedik saját fejlettségéről, ezzel párhuzamosan saját zenei képességeiről is (Janurik-Józsa, 2018).

Az ének-zene oktatásban leginkább az éneklés jelenthetné az aktív, örömteli zenélés lehetőségét. A diákok azonban nem kedvelik az éneklést sem énekórán, sem otthon, a maguk szórakoztatására; komoly- és könnyüzenét egyaránt nagyon ritkán énekelnek. Mind az éneklés örömteli tevékenységként való átélése, mind pedig a zenei percepcióhoz köthetö készségek fejlesztése, valamint ez utóbbi terület tudatositása kulcsfontosságú lehet az ének-zenéhez füződő pozitív attitüd kialakításában, amennyiben megfelelő módszerekkel sikerül erre késztetni a fiatalokat.

A zenetanulás fejlesztö hatásait több évtizedre visszanyúló hazai és nemzetközi kutatások támasztják alá. Ezek az eredmények azonban kevéssé jutnak el a szélesebb közönséghez, ily módon kevéssé járulhatnak hozzá a zenei nevelés népszerüsítéséhez, „hasznosságának” általános megítéléséhez. Fontos lenne annak tudatosítása, hogy a zenetanulás nemcsak az esztétikai és érzelmi fejlődés lehetőségét nyújtja - ami önmagában is érték -, de a zenei képességek fejlettsége összefügg az iskolai tanulás szempontjából meghatározóan fontos készségek, például a nyelvi, matematikai készségek fejlettségével (Janurik, 2008; Miendlarzewska-Trost, 2013; Tierney-Kraus, 2013a) és a tanulmányi eredményességgel is (például Janurik-Józsa, 2016). A zenetanulás és az intelligencia között szintén pozitív kapcsolat mutatható ki (például Esteki, 2013; Schellenberg-Weiss, 2013). 
A módszertani megújulást tekintve további fontos szempont lehet, hogy nemzetközi és hazai kutatási eredmények alapján a zenei percepció általános fejlettsége mellett az egyes képességek közül a ritmushallás jelentösége emelkedik ki (Janurik-Józsa, 2016; Tierney-Kraus, 2013b). A ritmikai készségek korai fejlesztésének jelentőségét mutatja, hogy az első évfolyamon mért fejlettségük az intelligencia és a szülői háttér magyarázóerejénél nagyobb mértékben járul hozzá a tanulmányi eredményességhez a hetedik osztályban (Janurik-Józsa, 2018).

Végül a digitális eszközök helyes és arányos használatát, valamint az ezekhez kapcsolódó digitális tananyag és oktatási módszerek kialakításának szükségességét emeljük ki. Korunk diákjainak életében fontos szerepet játszanak a digitális eszközök, amelyek hatására a korábbi generációkhoz képest nagyon eltérőek tanulási, ismeretszerzési, zenehallgatási, kommunikációs szokásaik is. A digitális eszközök használatával várhatóan érdeklődésük, motiváltságuk is fenntarthatóbb, és a zenetanulás eredményessége is növekedhet. Az ének-zene oktatás azonban eddig csak igen ritkán élt ezzel a lehetőséggel. Problémát jelent, hogy nincs naprakész digitális tananyag. Kevés magyar nyelvű szoftver és applikáció áll rendelkezésre, és elsősorban az alsó tagozaton hiányoznak azok a komplex programok, amelyek nyelvezetükben, arculatukban megfelelőek a korosztály számára. ${ }^{1}$ További problémát - és kihívást - jelent, hogy a zenetanárok többsége nem rendelkezik megfelelő digitális kompetenciával. A zenepedagógus-képzés és továbbképzés terén hiányoznak a digitális kompetencia fejlesztésének lehetőségei, az IKT- (Információs és kommunikációs technológiai) eszközök használatával kapcsolatos tárgyak, kurzusok nincsenek specializálva (Szabó, 2015).

\section{MÓDSZERTANI KUTATÁSOK AZ ÉNEK-ZENE OKTATÁS TERÉN}

Rövid áttekintésünk alapján látható, hogy az ének-zene oktatás súlyos problémákkal küzd, módszer- és eszköztárából hiányoznak a diákok számára optimális kihívást jelentő, élményt nyújtó tanulási lehetőségek. Mindezekkel párhuzamosan a tantárgy presztízsvesztése tovább súlyosbítja, szinte ellehetetleníti az ének-zene tanárok munkáját. A Magyar Tudományos Akadémia támogatásának köszönhetően a legfrissebb kutatási eredményeket felhasználva a fentebb vázolt problémák közül több területen is lehetőség nyílik a megújulásra.

\footnotetext{
${ }^{1}$ Néhány, magyar nyelven elérhető zenei képességfejlesztő és a zenei ismeretek elsajátítását segitő alkalmazás és internetes adatbázis: Manó Muzsika szolfézsoktató program: URL1, Madárszó táblagépes alkalmazás a szolmizáció és kottaírás megismertetésére kisiskolások számára: URL2, Sulinet tananyag az ének-zene oktatás számára: URL3.
} 
Az éneklést és zenehallgatást kísérő mozgásnak a zenepedagógiai gyakorlatba való integrálását tủzte ki célul a Liszt Ferenc Zeneművészeti Egyetem Kodály Intézete tanárainak, kutatóinak, valamint az MTA Természettudományi Kutatóközpont Agyi Képalkotó Központ munkatársainak részvételével kialakított interdiszciplináris munkacsoport. A témát két részről megközelítve kutatják. Az egyik modell Émile Dalcroze zenepedagógiai elveihez közelítően az irányított, zenét követő mozgásra alapoz, a második modell pedig az improvizált, szabad mozgást helyezi előtérbe Kokas Klára zenepedagógiája elemeinek felhasználásával. A zenepedagógiai modellek hatásvizsgálata mind zenei, mind nem zenei képességek (például nyelvi képességek, memória vagy figyelem) vizsgálatára is kiterjed, illetve ezek egymásra hatásának vizsgálatára is sor kerül (Maróti et al., 2016; Nemes, 2016).

Az SZTE (Szegedi Tudományegyetem) Zenemüvészeti Karának oktatóiból, valamint az SZTE Neveléstudományi Doktori Iskolájának oktatóiból és doktoranduszaiból alakult kutatócsoport a digitális eszközöknek az ének-zene órák gyakorlatában való felhasználását, valamint ritmikai fejlesztőprogram kialakítását és hatásvizsgálatát tűzte ki célul. A kutatócsoport által fejlesztett Zenesziget több platformon futó, megjelenésében és nyelvezetében az alsó tagozatos tanulók zenei oktatására tervezett szoftver. ${ }^{2}$

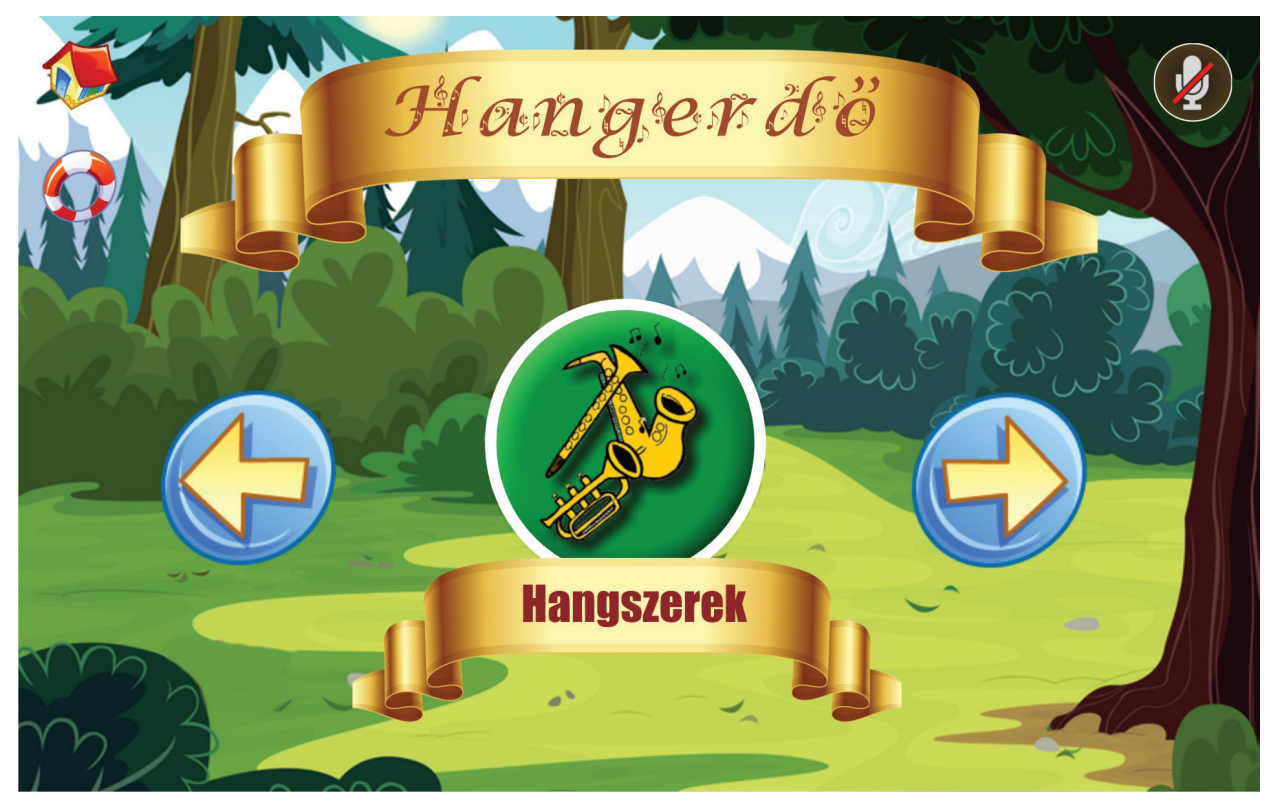

1. ábra. Képernyőkép a szoftverből, 1.

${ }^{2}$ A Zenesziget applikációt bemutató weboldal: URL4. 
A cél a tananyaggal összhangban alkalmazható, olyan játékos feladatok létrehozása, amelyek a hagyományos éneklés és ritmizálás mellett, a $\mathrm{Z}$ generáció igényeit figyelembe véve segítik a zenei készségfejlesztést, a zenei befogadást, ismeretelsajátítást, és támogatják a kreativitást. Felső tagozaton a már meglévő, az oktatásban jól használható szoftverek feltérképezése, és a használatukat elősegítő feladatbankok, módszerek kidolgozása a cél. A program során a diákok táblagépeken dolgozhatnak. A ritmikai fejlesztőprogram kialakításának célja pedig, hogy a ritmikai készségek játékos fejlesztésén keresztül a résztvevők a foglalkozások során kreatívan ritmust, zenét rögtönözve éljék át a társas muzsikálás örömét. A program összeállításánál fontos szempont, hogy a feladatok újszerủek, élményt adóak legyenek, együttmüködésre, alkotásra késztessenek. A hatásvizsgálatok mind a zenei fejlődésre, mind fontos kognitív készségek fejlödésére kiterjednek.

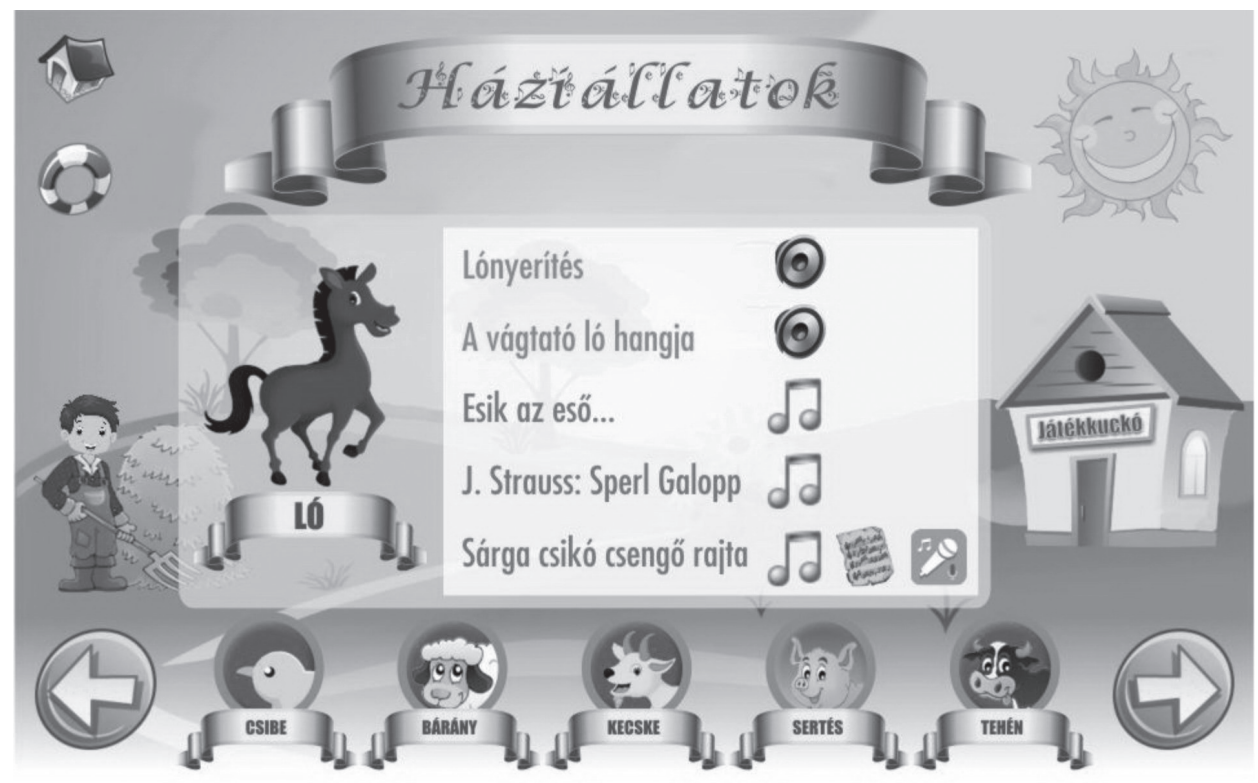

2. ábra. Képernyőkép a szoftverből, 2.

Mindkét kutatócsoport munkájában jelentős szerepet kap az intrinzik módon motivált, érdeklődésen és kreativitáson alapuló zenei képességfejlesztés, és a ritmussal összefüggő örömteli, aktív tevékenységek. Mindezeknek köszönhetően azt várhatjuk, hogy a programok a jövőben, a gyakorlati alkalmazás során hozzájárulhatnak az ének-zene órák élményszerübb átéléséhez, az oktatás módszertani és eszközbeli megújulásához. 


\section{KÖSZÖNETNYILVÁNITTÁS}

A tanulmányban szereplő kutatások az MTA-SZTE Ének-Zene Szakmódszertani Kutatócsoport kutató munkájához kapcsolódnak. A kutatásokat a Magyar Tudományos Akadémia Tantárgy-pedagógiai Kutatási Programja támogatja.

\section{IRODALOM}

Esteki, M. (2013): Effectiveness of "Music Training” on Reorganization of Brain and Poor Intellectual Abilities in Female Students with Dyscalculia (7-9 Years Old). Global Journal of Arts Education, 3, 2, 16-20. http://archives.sproc.org/index.php/gjae/article/view/2836/2285

Janurik M. (2008): A zenei képességek szerepe az olvasás elsajátításában. Magyar Pedagógia, 108, 4, 289-318. http://magyarpedagogia.hu/document/Janurik_MP1084.pdf

Janurik M. (2009): Hogyan viszonyulnak az általános és középiskolás tanulók a klasszikus zenéhez? Új Pedagógiai Szemle, 7, 47-64. http://folyoiratok.ofi.hu/sites/default/files/article_attachments/upsz_2009_7_04.pdf

Janurik M. - Józsa K. (2016): A zenei képességek összefüggése a DIFER készségekkel óvodáskorban. Neveléstudomány: Oktatás - Kutatás - Innováció, 4, 1, 49-69. http://nevelestudomany. elte.hu/downloads/2016/nevelestudomany_2016_1_49-69.pdf

Janurik M. - Józsa K. (2018): Az ének-zene oktatás helyzete és jelentősége. Egy longitudinális vizsgálat tanulságai. Közlésre benyújtva

Józsa K. - Kis N. - Huang, S. (2017): Mastery Motivation in School Subjects in Hungary and Taiwan. Hungarian Educational Research Journal, 7, 2, 158-177. http://herj.lib.unideb.hu/file/3/597798d37bcfc/szerkeszto/HERJ_2017_2_10.pdf

Maróti E. - Barabás E. - Deszpot G. et al. (2016): The Effect of Movement Instruction in Music Education on Cognitive, Linguistic, Musical and Social Skills. In: Proceeding ICMPC14 (14 ${ }^{\text {th }}$ Biennial International Conference on Music Perception and Cognition), San Francisco, CA, 544. http://www.icmpc.org/icmpc14/files/ICMPC14_Proceedings.pdf

Miendlarzewska, E. - Trost, W. (2013): How Musical Training Affects Cognitive Development: Rhythm, Reward and Other Modulating Variables. Frontiers in Neuroscience, 7, 279. DOI: 10.3389/fnins.2013.00279, https://www.frontiersin.org/articles/10.3389/fnins.2013.00279/full

Nemes L. N. (2016): Beszámoló előadás az „Aktív zenetanulás énekléssel és mozgással - módszerek és ezek hatásvizsgálata” c. kutatás tervezéséről. Parlando, 5, http://www.parlando. hu/2016/2016-5/Nemes-projekt.htm

Schellenberg, G. E. - Weiss, M. W. (2013): Music and Cognitive Abilities. In: Deutsch, D. (ed.): Psychology of Music, 12, 499-550. https://www.researchgate.net/publication/230753446_Music_and_Cognitive_Abilities

Szabó N. (2015): A digitális kotta mint digitális tananyag. Iskolakultúra, 25, 11, 53-74. http://www. iskolakultura.hu/ikultura-folyoirat/documents/2015/11/05.pdf

Tierney, A. - Kraus, N. (2013a): Music Training for the Development of Reading Skills. In: Merzenich, M. - Nahum, M. - Van Vleet, T. M. (eds): Progress in Brain Research, 207, 209-241. https://www.brainvolts.northwestern.edu/documents/Tierney_Kraus_Chapter_2014.pdf

Tierney, A. - Kraus, N. (2013b). The Ability to Tap to a Beat Relates to Cognitive, Linguistic, and Perceptual Skills. Brain and Language, 124, 3, 225-231. https://www.ncbi.nlm.nih.gov/pmc/ articles/PMC3594434/ 
URL1: http://www.profi-media.com/id-47-manomuzsika.html

URL2: https://create.mome.hu/index.php?option=com_content\&view=article\&id=354:madarszo\& catid $=61$ :interaktivkoenyv\&Itemid $=129 \&$ lang $=$ hu

URL3: http://kozosseg.sulinet.hu/hu

URL4: http://www2.u-szeged.hu/ezk/?page_id=325 